Nalar: Jurnal Peradaban dan Pemikiran Islam

Vol. 3, No. 1, Juni 2019

\title{
Hukum Tiga Tahap Auguste Comte dan Kontribusinya Terhadap Kajian Sosiologi Dakwah
}

\author{
Muhammad Chabibi \\ Institut Pesantren KH. Abdul Chalim Mojokerto \\ chabibi.akib@gmail.com
}

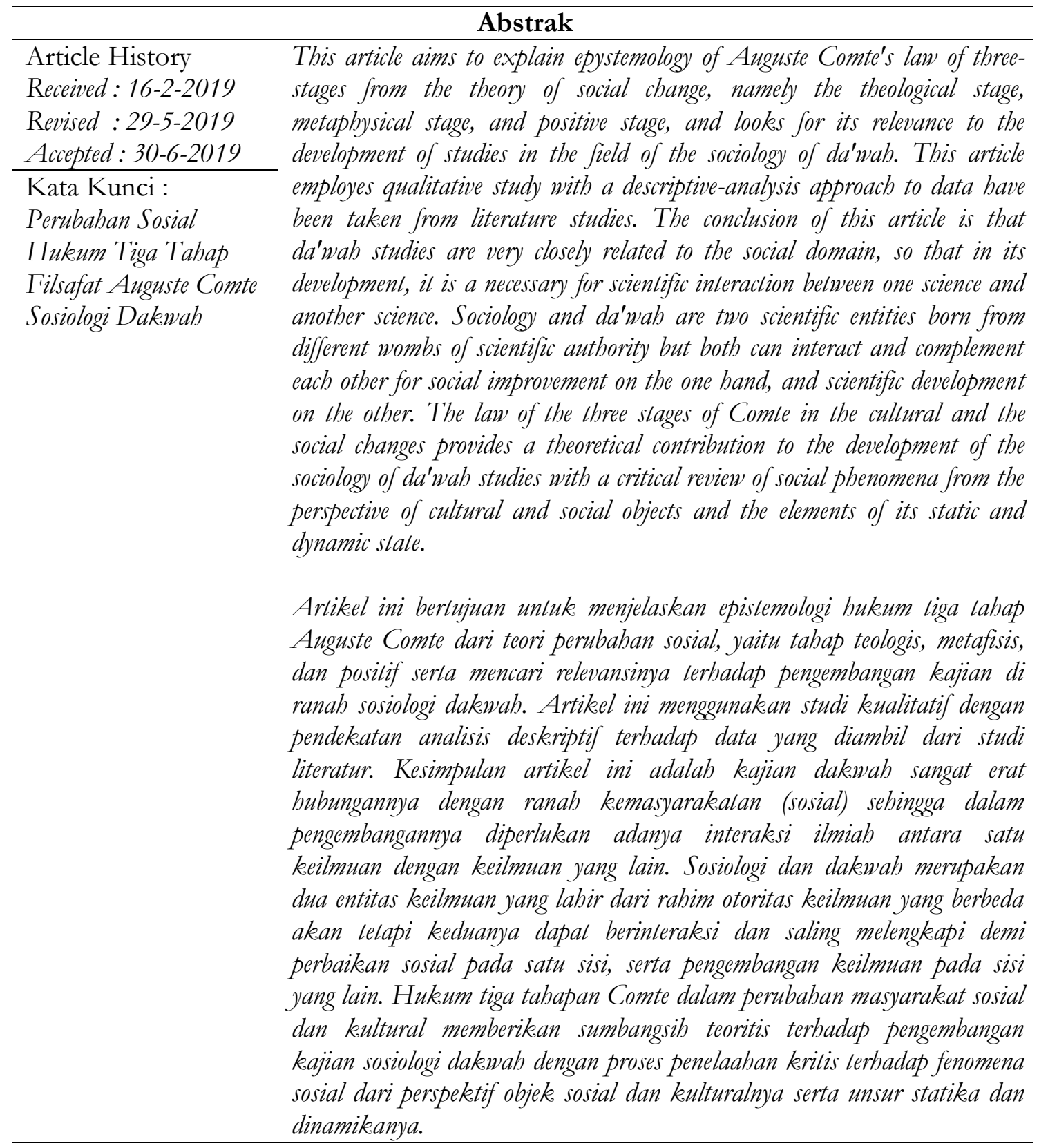

\section{Pendahuluan}

Keniscayaan yang pasti bagi kehidupan segala makhluk di dunia ini adalah perubahan. Semua materi mengalami perubahan, bahkan manusia sekalipun sesempurna apa pun bentuk manusia yang diciptakan oleh Tuhan, ia akan mengalami perubahan. Dan 
Nalar: Jurnal Peradaban dan Pemikiran Islam

Vol. 3, No. 1, Juni 2019

perubahan merupakan kehendak alamiah sebagai bagian dari kekuasaan Tuhan. Perubahan dapat dialami oleh setiap manusia baik individu maupun koloni (masyarakat). Perubahan dapat berupa perubahan menuju pada hal yang lebih baik atau sebaliknya perubahan menjadi semakin buruk.

Perubahan tidak hanya mengenai materi atau sesuatu yang bersifat kebendaan. Perubahan juga mengenai cara mempertahanakan hidup, perubahan cara berfikir, bertingkah laku dan perubahan dalam memperoleh kenikmatan duniawi. Itu semua mengenai kebudayaan dan peradaban manusia secara. Perdebatan mengenai perubahan, terutama terkait dengan perubaha sosial terus berlanjut sehingga arah dan laju perubahan pada berbagai tingkat kehidupan sosial seolah-olah tidak mungkin dapat dibendung. Perubahan sosial sebagai konsep yang menunjuk pada perubahan fenomena sosial pada berbagai tingkat kehidupan manusia mulai tingkat individual hingga tingkat dunia. Perubahan sosial dapat dipelajari pada satu tingkat tertentu atau lebih dengan menggunakan berbagai kawasan studi dan berbagai satuan analisis. Hal ini sebagaimana apa yang dilakukan oleh Auguste Comte (1798-1857), seorang pemikir sosial asal Perancis yang dianggap sebagai Bapak Sosiologi dan pendiri aliran Positivisme dalam sejarah perkembangan ilmu pengetahuan. Comte mencoba memberikan tawaran ilmiah dan pemahaman metodologis seputar ilmu pengetahuan tentang masyarakat manusia yang dikatakannya dengan istilah "fisika sosial" dan kemudian sosiologi.

Auguste Comte lahir di Montpellier, Perancis pada tanggal 19 Januari 1798 dan meninggal pada 5 September 1857 di Paris diakibatkan oleh penyakit kanker di perutnya. Nama aslinya adalah Isidore Auguste Marie Francois Xavier Comte, seorang filosof terkemuka di Perancis (Ritzer, 2014: 26).Auguste Comte memiliki proyek besar bersama seniornya Henry de Saint-Simon di dalam filsafat positif (positivisme). Walaupun SaintSimon adalah orang pertama kali yang menggunakan istilah positivisme namun A. Comte mempopulerkannya sehingga menjadi salah satu istilah baru dalam sejarah perkembangan filsafat ilmu. Selain itu, Auguste Comte pula memperkenalkan istilah sosiologi. Sebuah istilah yang dipahami Comte sebagai studi ilmiah terhadap masyarakat. Hal itu berarti masyarakat harus dipandang layaknya alam yang terpisah dari subjek peneliti dan bekerja dengan hukum determinisme. Comte (Positivisme) menjunjung tinggi fakta-fakta. Ia hanya menerima pengetahuan faktual. Fakta positif yaitu fakta yang terlepas dari kesadaran individu. Oleh karenanya, sosiologi sering disebutnya sebagai fisika sosial (suatu kajian tentang manusia dan masyarakat dianggapnya sama dengan alam yang memiliki hukumhukumnya yang pasti / bersifat mekanis).

Istilah "positif: kerap kali digunakan dalam tulisan Comte, yang maksudnya sama dengan filsafat positivismenya. Fakta positif adalah "fakta riil" atau "yang nyata". Hal positif (a positivefact) adalah sesuatu yang dapat diuji atau diverifikasi oleh setiap orang yang mau membuktikannya. Dengan proyek itu, Comte berdiri di garis depan mendirikan sosiologi atas dasar metode empiris yang teramati dan terukur (reliable-measureable) dengan mencontoh metode ilmu-ilmu alam (Lubis, 2014: 142). Seperti metode penelitian empiris pengamatan (observasi), eksperimen dan perbandingan (komparasi) (Martineau, 2000: 202).

Menurut Donny Gahral Adian (2002) filsafat positif atau aliran Positivisme merupakan evolusi lanjut dari empirisme Inggris. Filsafat empirisme memberikan inspirasi terhadap positivisme terutama prinsip objektivas ilmu pengetahuan. Kaum Empiris meyakini bahwa semesta adalah segala sesuatu yang hadir melalui data inderawi, dengan kata lain pengetahuan manusia harus berawal dari pengamatan empiris-inderawi. Positivisme mengembangkan klaim empiris tentang pengetahuan secara ekstrim dengan mengatakan bahwa puncak pengetahuan manusia adalah ilmu-ilmu berdasarkan pada fakta-fakta keras 
Nalar: Jurnal Peradaban dan Pemikiran Islam

Vol. 3, No. 1, Juni 2019

(terukur dan teramati), ilmu-ilmu positif (Positive Sciences).

Dalam pandangan aliran filsafat Positivisme, filsafat tidak punya kerja lain selain cara kerja ilmu pengetahuan. Ia bertugas menemukan prinsip-prinsip umum yang sama untuk semua ilmu dan menggunakan prinsip tersebut sebagai pemandu untuk perilaku manusia serta dasar untuk pengaturan sosial masyarakat. Positivisme yakin bahwa masyarakat akan mengalami kemajuan apabila mengadopsi total pendekatan ilmu pengetahuan dan teknologi. Dengan kata lain, aliran ini amat menjunjung tinggi kedudukan ilmu pengetahuan dan sangat optimis dengan peran sosialnua yang dapat dimainkan bagi kesejahteraan manusia. Muncul slogan bagi Positivisme "savoir pour prevoir, prevoir pour pouvoir" yang artinya "dari ilmu muncul prediksi dan dari prediksi muncul aksi"(Adian, 2002).

Artikel ini merupakan studi kualitatif yang bertujuan untuk membaca kembali epistemologi dari teori perubahan sosial "hukum tiga tahap" (law of three stages) yang digagas oleh Auguste Comte serta mencari kontribusinya terhadap pengembangan kajian sosiologi dakwah. Dalam proses penyusunan artikel ini, penulis menelusuri studi terdahulu yang berkaitan dengan sosiologi dakwah dan Auguste Comte sehingga penulis menemukan beberapa studi literatur seperti tulisan Juhari (2015) "Perubahan Sosial Dalam Perspektif Dakwah" yang menganggap perubahan sosial bukan hanya kajian yang dibahas oleh bidang sosiologi akan tetapi juga oleh kajian dakwah. Bahkan, dakwah itu sendiri memiliki karakteristik teoritis dengan prinsip tidak bebas nilai, berbeda dengan sosiologi yang lebih cenderung kepada prinsip bebas nilai (freevalues). Dalam perubahan sosial, dakwah diposisikan sebagai penawar dari segala permasalahan yang melanda umat. Perlu disadari bahwa permasalahan umat ini pun kini terus berkembang sehingga dibutuhkan dakwah sebagai penawar yang menarik serta aktual (Yazid, 2018). Studi lain berkaitan dengan Comte adalah artikel Nugroho(2016) yang berjudul "Positivisme Auguste Comte: Analisa Epistemologi dan Nilai Etisnya terhadap Sains". Fokus studi ini adalah positivisme Comte yang dianggapnya sebagai pengetahuan ilmiah yang paling valid dan terukur sehingga aliran ini menolak segala keberadaan kekuatan atau subyek di belakang fakta serta menolak penggunaan metode di luar fakta.

Dari pembahasan sedikit mengenai studi literatur tadi, artikel ini secara spesifik menekankan aspek karakteristik hukum tiga tahap yang dikembangkan oleh Auguste Comte serta kontribusinya terhadap kajian sosiologi dakwah. Oleh karna itu, kajian artikel ini memiliki perbedaan dengan studi-studi literatur yang telah dibahas dengan sedikiti tadi sehingga artikel ini dianggap perlu dengan alasan bahwa diskusi ilmiah mengenai sosiologi dakwah masih minim, terlebih lagi dalam perspektif hukum tiga tahapnya Comte. Selain itu, artikel ini bermanfaat bagi para praktisi dakwah untuk dapat membaca terlebih dahulu konteks kemasyarakatan dari perspektif sosiologi yang dibawa oleh Comte.

\section{Hukum Tiga Tahap Auguste Comte}

Auguste Comte tumbuh dari keluarga yang pandai dalam bidang matematika. Namun, latar belakang keilmuan Comte adalah fisika. Oleh karena itu, ia berusaha menerapkan cara berfikir ilmu alam (naturalscience) untuk mempelajari manusia sebagai makhluk sosial. Comte merupakan pengikut aliran positivisme yang meyakini bahwa masyarakat merupakan bagian dari alam. Setiap masyarakat memiliki pola (hukum) yang sama dalam proses perubahannya. Sementara peranan sosiologi bertugas untuk mempelajari serta menemukan hukum sosial yang sama tersebut. Penemuan hukum ini akan mempermudah dalam memprediksi kondisi kemajuan suatu masyarakat (Martono, 2016: 3940). Untuk itu metode-metode penetitian empirislah yang dapat dipergunakan untuk 
Nalar: Jurnal Peradaban dan Pemikiran Islam

Vol. 3, No. 1, Juni 2019

menemukan hukum-hukum sosial dalam masyarakat.

Di dalam kajian ilmu sosial, Comte membaginya menjadi dua pembahasan, yaitu statika sosial (social statics) dan dinamika sosial (social dynamic). Yang dimaksud dengan statika sosial adalah teori tentang keteraturan yang tidak direncanakan dari masyarakat manusia (theory of spontaneous order of human society) (Martineau, 2000), atau struktur-struktur sosial yang sudah ada (Rietzer, 2014: 24). Struktur ini relatif tidak berubah dalam waktu yang lama. Dan adanya struktur tersebut didasari pada asumsi bahwa masyarakat merupakan sebuah organisme yang disatukan oleh konsensus (kesepakatan) sehingga di dalamnya terjalin sebuah hubungan yang harmonis (Martono, 2016: 60). Meskipun demikian, pada sebenarnya statika sosial merupakan bagian yang paling elementer di dalam sosiologi, hanya saja dia bukanlah bagian yang paling penting di dalam studi tentang sosiologi, karena pada dasarnya statika sosial merupakan hasil dari suatu pertumbuhan (Anwar, 2013: 122).

Adapun dinamika sosial adalah teori tentang kemajuan alami dari masyarakat manusia (theory of natural progress of human society), atau teori tentang perkembangan dan kemajuan masyarakat, atau studi mengenai tata urutan perkembangan manusia (Martineau, 2000; Martono, 2016). Studi ini mengacu pada pembahasan mengenai proses perubahan sosial dalam masyarakat manusia. Dan menurut Auguste Comte, dinamika sosial inilah merupakan bagian yang paling penting dari kajian sosiologi, karena ia dengan ilmu pengetahuan yang bersifat positif akan dapat mengalahkan sifat spekulatif yang dibawa oleh filsafat dalam menjaga keteraturan tatanan sosial yang ada (Turner, 2012: 9).

Pembagian sosiologi ke dalam dua bagian tersebut bukan berarti akan memisahkan satu sama lain. Ibarat rumah, maka statika sosial merupakan bangunan rumahnya yang relatif tidak berubah atau statis bentuknya dalam waktu yang lama, sementara dinamika sosial merupakan isi rumah dan aktivitas manusia yang ada di dalamnya. Apabila statika sosial merupakan studi tentang keteraturan sosial yang ada di antara masyarakat yang saling berhubungan (struktur sosial) dan akan menghasilkan pendekatan yang paling elementer terhadap sosiologi, tetapi studi tentang hubungan-hubungan sosial yang terjadi antara bagian-bagian itu tidak akan pernah dapat dipelajari tanpa memahaminya sebagai hasil dari suatu perkembangan. Oleh karena itu, Comte berpendapat bahwa tidaklah akan diperoleh suatu pemahaman yang layak dari suatu masalah sosial tanpa menggunakan pendekatan dinamika sosial atau teori tentang perkembangan manusia (Anwar, 2013).

Pemikiran Auguste Comte tentang teori sosial tersebut dilatarbelakangi oleh adanya pergolakan sosial politik yang terjadi di Perancis. Suatu pergolakan yang disebut-sebut sebagai aksi revolusi Perancis telah menimbulkan kehancuran dan kehidupan anarki yang dialami oleh masyarakat Perancis. Masyarakat diancam oleh kekacauan intelektual dan sosial politik untuk mendapatkan kehidupan yang lebih teratur, sehingga muncul kaum intelektual Perancis masih ingin berpegang pada keyakinan untuk kembali pada Abad Pertengahan dan hal ini dikritisi serta diprotes oleh Auguste Comte bahwa tidak mungkin untuk kembali ke Abad Pertengahan di mana kemajuan-kemajuan di bidang ilmu dan industri (abad Pencerahan) membuat hal tersebut menjadi mustahil dan absurd (Ritzer, 2014).

Dalam pandangan Bryan S. Turner, pemikiran sosial abad Pencerahan bercirikan sebuah utopianisme tertentu, yang merupakan cerminan dari keyakinan terhadap janji-janji modernitas untuk membawa kebebasan. Tidak seperti pemikiran sosial yang ada pada sebelumnya, pemikiran sosial abad Pencerahan menunjukkan keyakinan yang besar terhadap kekuatan tindakan manusia untuk membentuk masa depan. Dan sepertinya, pengaruh pemikiran utopia dan masalah mengenai keteraturan tatanan sosial pada masa revolusi Perancis tersebut turut mempengaruhi keyakinan rasionalitas Comte (Turner, 2012). 
Nalar: Jurnal Peradaban dan Pemikiran Islam

Vol. 3, No. 1, Juni 2019

Pemikiran utupia tersebut muncul dari tuntutan masyarakat terhadap keharusan adanya kebebasan, persamaan dan persatuan, serta tuntutan moralitas intelektual dan kemerdekaan filosofis yang nantinya akan menjadi tonggak sejarah lahirnya para pemikir abad ke-18. Kepercayaan ahli filsafat Pencerahan tersebut berupa adanya kemampuan akal budi manusia untuk mengubah masyarakat sesuai dengan prinsip-prinsip ilmiah tidak terbatas. Meskipun demikian, Auguste Comte sesungguhnya dipengaruhi oleh kepercayaan Abad Pencerahan tersebut akan ilmu pengetahuan, namun Comte memiliki rasa tidak percaya pada kelompok konservatif terhadap individualisme abad Pencerahan serta tekanan kelompok konservatif pada pentingnya mempertahankan keteraturan sosial melawan ancaman anarki sosial (Beni, 2016: 50-51).

Oleh karenanya, Comte memiliki pandangan yang rasional dan futuristik tentang suatu masyarakat. Kejadian fenomena perubahan sosial masyarakat Perancis yang dialaminya tersebut memberikan pondasi keilmuan Comte tentang teori kemajuan manusia dan evolusionisme sosial, yaitu pada saat aristokrasi yang turun-temurun dapat diganti oleh persamaan. Takhayul dan ketakutan dapat diganti oleh akal budi dan percaya diri. Kerja paksa dapat diganti oleh kerja sama sukarela. Dan dominasi agama dapat diganti oleh dominasi ilmu pengetahuan (Beni, 2016). Pada akhirnya teori itu mengusulkan bahwa ada tiga tahap intelektual (law of three stages) yang dilalui oleh manusia di sepanjang sejarahnya.

Menurut Comte, bukan hanya dunia saja yang melalui proses perkembangan dinamis atau evolusi (natural progress) akan tetapi kelompok, masyarakat, ilmu, individu dan bahkan pikiran manusia pun akan melalui tiga tahap. Dan hukum tiga tahap (law of three stages) adalah rumusan perkembangan masyarakat dan individu yang bersifat evolusioner. Kekuatan perubahan sejarah manusia diawali oleh dorongan semangat manusia untuk berkembang dan maju melalui pikiran atau intelegensianya. Dengan semangat itulah manusia memahami realitas, berasumsi dan membuat metode yang diterapkan dalam upaya menjelaskan, memprediksi dan mengendalikan kehidupan masyarakat. Kualitas dan kuantitas pengetahuan yang dimiliki masyarakat terus berkembang. Derajat pengetahuan yang dimiliki masyarakat mempengaruhi atau menentukan semua aspek kehidupan bermasyarakat lainnya seperti ekonomi, politik dan militer (Martono, 2016: 118).

Perubahan sosial selalu berubah dari hal yang sederhana ke arah yang lebih kompleks, selalu berubah dari kehidupan biasa menuju kemajuan. Perkembangan perubahan sosial suatu masyarakat akan mengikuti pola linear yang terdapat pada hukum tiga tahap. Hukum ini merupakan generalisasi dari tiap tahapan intelegensia manusia yang berkembang semakin maju melalui tiga tahapan (law of three stages/states): tahap teologis (the theological stage), tahap metafisik (the metaphysical stage) dan tahap positif atau ilmu pengetahuan (the positive stage) (Bourdeau, Michel; Pickering, Mary \& Schmaus, 2018; Gane, 2006; Ladyman, 2002; Martineau, 2000).

Gambar 1. Pola Linear Teori Tiga Tahap

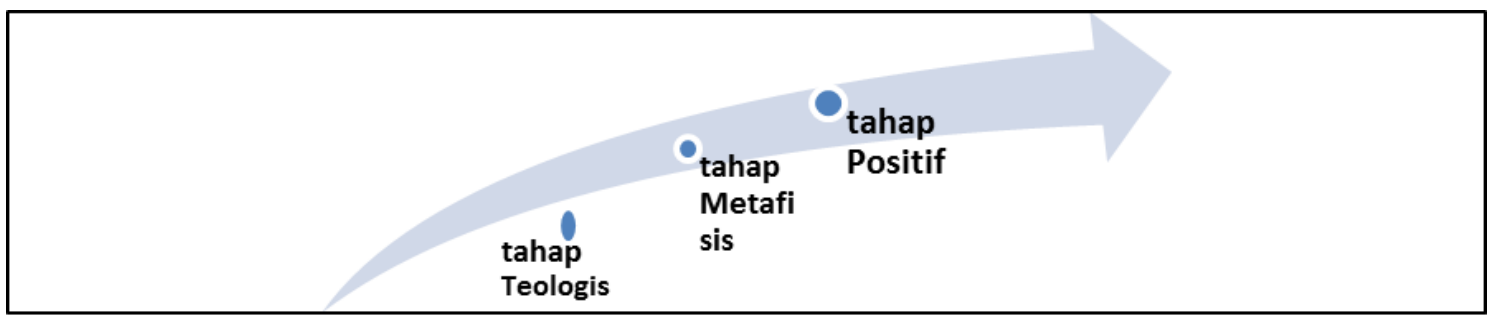

Sumber: Disarikan dari buku Nanang Martono yang berjudul Sosiologi Perubahan Sosial (2016). 
Nalar: Jurnal Peradaban dan Pemikiran Islam

Vol. 3, No. 1, Juni 2019

Penjelasan pola linear teori tiga tahap adalah sebagai berikut:

Pertama, Tahap Teologis dan Militer (Teologis). Tahap ini merupakan periode paling lama dalam sejarah manusia dan disebut sebagai masa kekanakan intelegensia manusia. Pada tahap ini manusia mempercayai adanya kekuatan-kekuatan supranatural yang muncul dari kekuatan zat adikodrati atau jimat atau kekuatan yang berasal dari luar diri manusia atau muncul dari kekuatan tokoh-tokoh agamis yang diteladani oleh manusia. Dalam kehidupan sosial, masyarakat di sini hidup berdasarakan pada penaklukan, yaitu hubungan sosial bersifat militer yang senantiasa menaklukkan dan menundukkan masyarakat lain. Oleh karenanya, pada tahapan ini pula terbagi menjadi tiga sub-tahapan, yaitu: fetisisme, politheisme dan monotheisme.

Fetisisme ialah suatu bentuk pikiran yang dominan dalam masyarakat primitif, meliputi kepercayaan bahwa semua benda memiliki kelengkapan kekuatan hidupnya sendiri (roh-roh). Dan manusia pada tahap ini mulai mempercayai kekuatan jimat atau benda. Fase ini pula dapat dikatakan sebagai fase awal sistem teologis dan militer.

Politheisme ialah anggapan yang muncul karena ada kekuatan-kekuatan yang mengatur kehidupan atau gejala alam (dewa-dewa atau makhluk ghaib). Pada tahap ini sudah muncul kehidupan kota, pemilikan tanah menjadi institusi sosial, adanya sistem kasta dan perang dianggap sebagai satu-satunya cara menciptakan atau meraih kehidupan politik yang kekal. Fase ini dapat pula dikatakan sebagai fase pengembangan sistem teologi dan militer.

Monotheisme ialah kepercayaan pada dewa yang mulai digantikan dengan zat tunggal atau hanya Tuhan yang berdaulat dan berkuasa untuk mengendalikan alam ini. Fase ini dapat dikatakan sebagai fase modifikasi sistem teologi dan militer. Modifikasi sistem militer (militerisme) yang dimaksud adalah suatu hubungan sosial masyarakat bersifat militer di mana masyarakat senantiasa bertujuan untuk menundukkan dan menaklukkan masyarakat lain.

Gambar 2. Pola Linear Teori Tiga Tahap

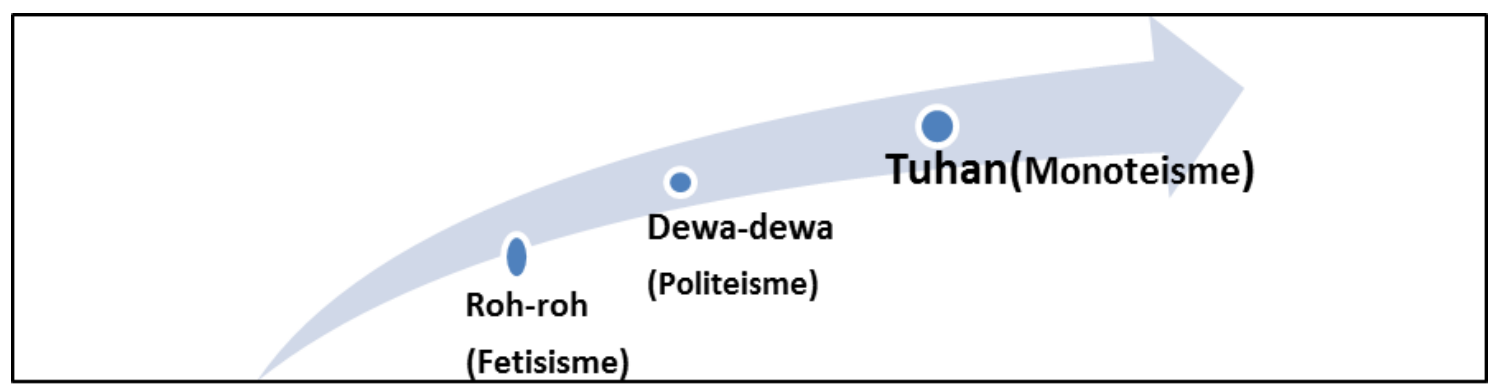

Sumber: Disarikan dari buku Nanang Martono yang berjudul Sosiologi Perubahan Sosial (2016).

Kedua, Tahap Metafisik (Revolutionary crisis). Tahapan ini merupakan fase transisi antara tahap teologis menuju ke tahap positfistik sehingga disebut dengan masa remaja intelegensia manusia. Tahap ini ditandai dengan adanya satu kepercayaan manusia akan hukum-hukum alam secara abstrak yang diilustrasikan dengan bentuk pemikiran yang bersifat filosofis, abstrak dan universal. Jadi, kepercayaannya bukan lagi kepada kekuatan dewa-dewa yang spesifik akan tetapi pemikiran manusia terbelenggu oleh konsep filosofis dan metafisis yang ditanamkan oleh filosof maupun orang agamawan secara abstrak dan universal (agen-agen ghaib digantikan dengan kekuatan abstrak), seperti "Akal Sehat"nya Abad Pencerahan. 
Nalar: Jurnal Peradaban dan Pemikiran Islam

Vol. 3, No. 1, Juni 2019

Dalam kehidupan sosial, masyarakat tidak lagi bersifat militer akan tetapi juga belum bersifat industrial. Pada konteks masa ini tujuan utama masyarakat bukan berupa penaklukan saja tetapi diperkuat dengan adanya peningkatan produksi, sehingga sistem perbudakan individual memang bergeser terhapus akan tetapi perbudakan yang dimiliki oleh produsen masih memperoleh berbagai haknya dalam hubungannya dengan militer. Oleh karenanya ada dua tujuan aktifitasnya yaitu penaklukan dan produksi. Produsen dilindungi sebagai suatu sumber kemiliteran dan perang dianggap secara sistematik penting untuk mengembangkan tingkat produksinya. Artinya tahapan ini merupakan jembatan atau tahap transisi dari masyarakat militer (primitif) menuju industri.

Ketiga, Tahap Positif dan Ilmu Pengetahuan (scientific stage). Tahap ini merupakan tahap terakhir dalam pemikiran evolusionisme sosial Auguste Comte dan dianggap sebagai masa dewasa intelegensia manusia. Pada tahap ini pikiran manusia tidak lagi mencari ide-ide absolut yang asli, yang menakdirkan alam semesta dan menjadi penyebab fenomena. akan tetapi pikiran manusia mulai mencari hukum-hukum yang menentukan fenomena, atau menemukan rangkaian hubungan yang tidak berubah dan memiliki kesamaan (tahap berfikir secara ilmiah). Tahap ini manusia mulai mempercayai data empiris sebagai sumber pengetahuan terakhir namun bersifat sementara dan tidak mutlak. Namun, melalui analisis sosial tersebut memungkinkan manusia dapat merumuskan hukum-hukum yang seragam, sehingga manusia mulai maju dan berkembang di depan ilmu pengetahuan.

Dalam kehidupan sosial, manusia dicetak untuk mampu menerapkan dan memanfaatkan akal budinya untuk menguasai lingkungan alam bagi kemajuan masa depan yang lebih baik. Masyarakat pada tahapan ini adalah masyarakat industri, di mana relasirelasi mereka merupakan bentukan-bentukan dasar industrial. Dan tahapan ini menunjukkan bahwa industri mendominasi hubungan sosial masyarakat secara kolektif yang diorganisasikan dan produksi adalah menjadi tujuan utama masyarakat.

Tabel 1. Tahapan Evolusi Pengetahuan Manusia dan Masyarakat

\begin{tabular}{|c|c|c|c|}
\hline & Teologis & Metafisis & Positif \\
\hline $\begin{array}{c}\text { Tahap } \\
\text { Pengetahuan }\end{array}$ & Fiktif, Supranatural, Teologis & $\begin{array}{l}\text { Abstrak, spekulatif- } \\
\text { filosofis, metafisis-kritis }\end{array}$ & Ilmiah, Empiris \\
\hline Landasan & Kepercayaan, Kebiasaan & Filsafat, Konsep & Logika Rasional, \\
\hline Pengetahuan & & Absolut & Observasi Ilmiah \\
\hline $\begin{array}{c}\text { Otoritas } \\
\text { Pengetahuan }\end{array}$ & $\begin{array}{c}\text { Para Tokoh Kepercayaan, Militer, } \\
\text { kependetaan }\end{array}$ & $\begin{array}{c}\text { metaphysician, Pemikir, } \\
\text { pembicara agama, juru } \\
\text { hukum (legalistik) }\end{array}$ & $\begin{array}{l}\text { Ilmuwan, usahawan } \\
\text { Industri, filosof } \\
\text { positif }\end{array}$ \\
\hline Fase peradaban & Mesir Kuno-Abad Pertengahan & Abad kedelapanbelas & $\begin{array}{l}\text { Abad modern } \\
\text { (revolusi Perancis) }\end{array}$ \\
\hline $\begin{array}{c}\text { Struktur } \\
\text { Masyarakat }\end{array}$ & $\begin{array}{l}\text { Masyarakat teologis, masyarakat } \\
\text { primitif, militerisme }\end{array}$ & $\begin{array}{l}\text { Masyarakat dogma, } \\
\text { masyarakat agraria }\end{array}$ & $\begin{array}{l}\text { Masyarakat industri, } \\
\text { masyarakat ilmiah }\end{array}$ \\
\hline
\end{tabular}

Sumber: disarikan dari buku Love, Order, Progress: The Science, Philosophy \& Politics of Auguste Comte

(Bourdeau, Michel; Pickering, Mary \& Schmaus, 2018)

\section{Kontribusi Hukum Tiga Tahap Terhadap Kajian Sosiologi Dakwah}

Di dalam pengembangan sosiologi, Auguste Comte menginginkan studi sosial lebih diarahkan pada aspek ilmiah, sehingga keseluruhan sistem pengetahuannya menjadi "positif' yang mencirikan pada kepastian, ketelitian, kenyataan, berguna, serta bersifat konstruktif dan relatif. Oleh karenanya, ilmu pengetahuan dalam studi sosial seharusnya bersifat homogeneous dan terintegrasi dalam artian bahwa semua cabang studi sosial harus mengaplikasikan metode saintifik positif dan objek studi yang umum demi kemajuan 
Nalar: Jurnal Peradaban dan Pemikiran Islam

Vol. 3, No. 1, Juni 2019

peradaban sosial. Kebutuhan studi-studi sosial pada formulasi saintifik diharuskan bagi Comte, dengan alasan bahwa kebutuhan manusia sudah saatnya mengarah pada metode baru (positif) dalam pengkajian ilmu sosial dan tidak hanya terpatri pada teori-teori tentang emosional dan intelektual yang dikembangkan oleh otoritas pengetahuan pada tahap teologis dan metafisis saja. Oleh karenanya, pengetahuan kemasyarakatan manusia perlu diperluas pada teori sains dan industri (Gane, 2006: 4).

Dalam pengembangan masyarakat sosial, Comte berupaya untuk memperbaiki kehidupan manusia dan pemikirannya dengan positivistiknya. Manusia secara individual dan sosial menempati posisi yang unggul yaitu di tahap ilmiah (positivis) sehingga ia dapat menjadi masyarakat ilmiah dan berkebudayaan humanis dan teratur (organis). Kendati demikian, Comte sendiri tidak bermaksud bahwa manusia harus meninggalkan model pemikiran dan kehidupan yang ada pada tahapan-tahapan sebelumnya (teologis dan metafisis) akan tetapi tujuan utama kemasyarakatan adalah hidup dalam rasa humanisme yang tinggi. Namun, untuk menuju kesana maka perlu beberapa hal dari masyarakat tahapan teologis dan metafisis yang harus dihindari misalnya keyakinan absolutisme terhadap dogma-dogma teologis dan kepatuhan absolut terhadap pemuka agama dan tokoh ideolog (bapaisme-ibuisme). Selain itu yang perlu dihindari adalah penyelesaian masalah dengan cara berperang (militeristik) sebagaimana yang diterapkan pada masyarakat teologis (primitif) serta model penaklukan terhadap manusia yang dilakukan oleh masyarakat metafisis demi tercapainya peningkatan produksi dan ekonomi. Masyarakat yang ideal adalah masyarakat yang lebih mengedepankan ilmu dan pengetahuan dari pada masyarakat yang hanya bermodal percaya dan kepatuhan buta, sehingga masyarakat ilmiah lebih mendahulukan pencarian data dan fakta empiris sebagai sumber pengetahuan namun bersifat sementara dan tidak mutlak dari pada kepercayaan buta terhadap sebuah fenomena dan peristiwa. Dari sini, masyarakat ilmiah (positifis) bukan hanya dianggap sebagai masyarakat yang unggul dalam intelegensia saja akan tetapi juga unggul dalam dimensi sosial sehingga masyarakat tidak hidup dalam kebrutalan, kekerasan dan keinginan penaklukan terhadap manusia lainnya tetapi lebih hidup dalam keharmonisan, keteraturan dan kemanusiaan.

Sementara, kajian dakwah sangat erat hubungannya dengan ranah kemasyarakatan (sosial) sehingga dalam pengembangannya diperlukan adanya interaksi ilmiah antara satu keilmuan dengan keilmuan yang lain. Tanpa mengurangi karakteristik dari masing-masing keilmuan dakwah dan sosiologi, ranah ilmiah (scientific domain) dapat dijangkau dan berinteraksi oleh keduanya. Dakwah tidak akan dapat memberikan dampak dan pengaruh terhadap masyarakat dalam konteks mengajak kebaikan apabila para pendakwah tidak mengetahui struktur sosial serta landasan pengetahuan yang dimiliki oleh sasaranya (almad' $\hat{\imath}$. Dan sebaliknya, sosiologi sebagai manfaat praktis, tidak akan memberikan pengaruh yang signifikan terhadap perbaikan sosial secara praktis apabila tidak disertai dengan penguatan nilai-nilai religius (dakwah) dengan konstruk sosial masyarakat yang cenderung hidup dalam kehidupan sosial-religius. Oleh karna itu, sosiologi dan dakwah merupakan dua entitas keilmuan yang lahir dari rahim otoritas keilmuan yang berbeda akan tetapi keduanya dapat berinteraksi dan saling melengkapi demi perbaikan sosial pada satu sisi, serta pengembangan keilmuan pada sisi yang lain.

Berkaitan dengan dakwah, menurut Waardenburg (2002: 301-302) keilmuan dakwah adalah jenis khusus dari bidang komunikasi. Pendakwah mengajak dan menyampaikan pesan kepada orang tertentu atau kepada khalayak (audience) untuk mengerahkan (mobilize) mereka kepada komitmen-komitmen tertentu tentang Islam. Dalam banyak kasus, dakwah memiliki sebuah karakter ritual, akan tetapi ia juga dapat menjadi lebih sekedar dari urusan sifat dan ekspresi personal seperti komitmen keagamaan, sosial atau bahkan politik. 
Nalar: Jurnal Peradaban dan Pemikiran Islam

Vol. 3, No. 1, Juni 2019

Pandangan tersebut diperkuat dengan pernyataan ulama' Mesir yang bernama Muhammad al-Ghazali (1998; 5) yang mengatakan bahwa kelahiran dakwah bersamaan dengan kelahiran akidah. Dengan dakwah dan akidah tersebut terlahirlah ibadah, akhlak, dan nilai-nilai sosial. Inti dari dua pendapat ini adalah dakwah menjadi keilmuan yang khas bagi studi keislaman dan kemasyarakatan sehingga konsepsi "ajakan" dalam ilmu dakwah dapat dipahami sebagai cara ilmiah untuk membuat perubahan serta perbaikan pada sektor sosial dan kemanusiaan. Namun, upaya tersebut tidak bisa membuahkan hasil yang maksimal serta tepat guna jika tidak mendalami transformasi struktural yang terdapat pada masyarakat itu sendiri.

Kajian sosiologi dakwah tidak dapat lepas dari konteks keilmuan sosiologi itu sendiri. Dan sosiologi itu pun merupakan cabang ilmu sosial. Ruang lingkup ilmu sosial adalah keseluruhan disiplin yang berhubungan dengan manusia dalam arti bukan sebagai bagian dari alam belaka, tetapi wujudnya manusia membentuk kehidupan bermasyarakat (sosial) dan berbudaya (kultural) (Mannheim: 1987). Dalam pandangan Acep Aripudin (2013: 6), kajian sosiologi dakwah memiliki ruang kajian yang begitu luas sebagaimana sosiologi pada umumnya, sehingga sosiologi dakwah mengkaji keseluruhan interaksi masyarakat dakwah, yang mencakup hubungan dakwah dengan ekonomi, politik, pendidikan, wanita, lingkungan hidup dan seterusnya, baik pada ranah subjek dakwah (dä̀), objek dakwah (mad'u), materi dakwah, media serta tujuan dakwah. Terlebih lagi, aktivitas dakwah dilakukan bertujuan untuk memengaruhi serta mengubah tingkah laku seseorang atau masyarakat dengan cara yang persuasif dan humanis, bukan koersif dan inhumanis (cara paksa, teror dan menakuti) sehingga tujuan ini menjadi konsekuensi aksiologis dari suatu disiplin ilmu.

Mengenai teori hukum tiga tahap. Auguste Comte selain dikenal sebagai pelopor filsafat positifistik, ia juga dikenal sebagai bapak Sosiologi dengan berbagai teori-teori sosialnya(Bourdeau, Michel; Pickering, Mary \& Schmaus, 2018; Gane, 2006; Ladyman, 2002). Khusus untuk teori hukum tiga tahap, istilah "tahapan" sebenarnya terdapat keragaman kata dalam bahasa inggris misalnya ada yang menyebutkannya dengan "three stages" (tiga tahapan), "three phases" (tiga fase) dan "three states" (tiga negara)(Bourdeau, Michel; Pickering, Mary \& Schmaus, 2018; Gane, 2006; Ladyman, 2002; Martineau, 2000). Akan tetapi menurut Gane (2006) hukum tersebut condong lebih disebut kepada istilah "law of three states" dengan keaslian bahasa Perancisnya "'loi des trois états"yang berarti hukum tiga negara. Dari hukum tiga negara tersebut, Comte mengklaim bahwa dia telah berhasil dalam menemukan objek fundamental serta logika saintifik baru, sehingga dia mendirikan kajian sosiologi modern.

Istilah "tahapan" lebih sering digunakan dengan alasan bahwa teori evolusi Comte meyakini bahwa masyarakat oleh suatu hukum universal yang berlaku kepada setiap orang di atas bumi ini. Hal ini didasari oleh asumsi dasar Comte tentang adanya kesamaan struktur indera dan akal budi manusia yang menghasilkan persepsi dan kesimpulan-kesimpulan logis yang sama pula. Oleh karenanya, perkembangan manusia di seluruh dunia memiliki ciri keteraturan sesuai dengan hukum universal tersebut (Erzioni: 1973). Bukan itu saja, dalam pandangan Judistira K. Garna (1992: 36), tiga tahapan perkembangan pemikiran manusia tersebut-teologis, metafisis, positifistik-merupakan dasar untuk tiga bentuk sejarah organisasi sosial masyarakat.

Di sini, penulis akan lebih sering menggunakan hukum tersebut sebagai tiga tahapan daripada negara maupun fase. Sekalipun, hukum tiga tahapan Comte-teologis, metafisis, positifistik-mendapatkan perhatian serius bagi sejumlah ilmuwan serta filosof sosial baik dalam bentuk apresiasi maupun kritikan. Hukum tiga tahap ini memberikan pengaruh terhadap perkembangan kajian-kajian sosial dan politik. Terlebih lagi dalam kajian 
Nalar: Jurnal Peradaban dan Pemikiran Islam

Vol. 3, No. 1, Juni 2019

keislaman, dakwah sudah seharusnya dapat menyapa serta berinteraksi secara ilmiah dengan beberapa teori yang ada di dalam kajian sosiologi. Upaya interaksi metode ilmiah ini dapat mengantarkan praktisi/akademisi kepada puncak intim dari relevansi teori hukum tiga tahap Comte terhadap pengembangan kajian sosiologi dakwah.

Penting bagi akademisi dan praktisi dakwah menelaah fenomena sosial dari perspektif objek sosial serta kulturalnya. Sosial dan kultural sebagai suatu sektor dakwah dilihat dari sejauhmana objek sosial dan kultur tersebut mempengaruhi atau terpengaruhi terhadap fenomena sosial. Dalam pandangan penulis, sektor sosial dan kultur dapat saja menjadi struktur atau order setting pada satu sisi dan dapat menjadi suatu perubahan atau berkembang (progress). Meminjam istilah Auguste Comte untuk sisi yang pertama disebut dengan "social statics" sedangkan sisi yang kedua disebut "social dynamics"(Martineau, 2000). Dalam konteks social statics, perlu dicermati adanya bagian-bagian struktural dari masyarakat yang tertata secara natural (theory of spontaneous order of human society). Struktur ini relatif tidak berubah dalam waktu yang lama. Dan adanya struktur tersebut didasari pada asumsi bahwa masyarakat merupakan sebuah organisme yang disatukan oleh konsensus (kesepakatan) sehingga di dalamnya terjalin sebuah hubungan yang harmonis (Martono, 2016: 40). Sedangkan social dynamics dapat dikatakan bahwa masyarakat mempunyai perkembangan dan kemajuan (theory of natural progress of human society)(Martineau, 2000). Bagi sektor sosial dan kultural, social statics dianalogikan dengan bangunan struktur rumah sementara social dynamicsnya dianalogikan dengan isi perabotan rumah dan aktivitas manusia yang ada di dalamnya. Dengan demikian, dalam membaca fenomena sosial-dakwah, baik sektor sosial dan kultural masyarakat masing-masing memiliki nilai guna dan nilai makna. Pada sektor sosial, nilai gunanya terletak pada sifat-sifat sosial dari masyarakat tersebut. Sementara pada sektor kultural, baik nilai guna dan nilai makna secara inheren terdapat pada sifat-sifat penanda objek tersebut. Sektor sosial dapat berupa apa yang diproduksi dan dikonsumsi oleh masyarakat sosial. Dan sektor kultural dapat berupa simbol, informasi dan representasi dari objek masyarakat tersebut.

Misalnya masyarakat dalam hukum tiga tahap terdapat masyarakat teologis, metafisis dan positif. Memahami fenomena sosial-dakwah yang terletak pada masyarakat teologis akan memiliki perbedaan dengan pemahaman akademisi/praktisi dakwah terhadap masyarakat metafisis. Dan ini berbeda pula terhadap masyarakat positif. Dalam kaitannya sosial dan kultural sebagai sektor dakwah, maka kajian sosiologi dakwah untuk masyarakat teologis sudah barang tentu harus dipersiapkan strategi-strategi dan aplikasi teori dakwah yang sesuai dan diadaptasikan dengan tahapan perkembangan masyarakat di pola pengetahuan yang teologis. Namun, apabila kondisi tersebut dipaksakan untuk mengaplikasikan strategi yang ada pada masyarakat positif maka tentu sasaran dakwah tersebut akan sulit untuk diterima. Bahkan pemaksaan tersebut justru menghilangkan sisi persuasif dan humanisnya sebuah keilmuan dakwah dalam perspektif aksiologis. Sebaliknya, apabila objek masyarakat dakwah itu adalah masyarakat positif dengan pendekatan pola pengetahuan teologis maka materi dan kandungan dakwah akan terlihat sederhana dan tidak memberikan kesan dalam perubahan sikap (attitude), perilaku (behaviroral) dan pengetahuannya (knowledge). Dalam contoh kasus terakhir tersebut, masyakarat (mad'u) hanya terkesan dengan pola-pola simbolik yang direpresentasikan oleh sang da'i seperti spontanitas humor, keindahan suara, dan personifikasi.

Masyarakat teologis digambarkan oleh Comte sebagai masyarakat yang masih hidup dan memegang teguh kepercayaan adikodrati, masyarakat metafisis sebagai masyarakat tengah-tengah dan memiliki kekuatan logika dan nalar filosofis dan masyarakat positif sebagai masyarakat yang gemar dengan kajian-kajian ilmiah. Dalam struktur masyakaratnya, 
Nalar: Jurnal Peradaban dan Pemikiran Islam

Vol. 3, No. 1, Juni 2019

dakwah terhadap masyarakat teologis perlu melihat dan menalaah fenomena sosial dan kultural yang melingkupi pada diri mereka atau dengan meminjam istilah Comte masyarakat primitif. Pengistilahan masyarakat primitif oleh Comte tersebut merupakan konsekunsi teoritis yang dikeluarkan oleh sosiolog Barat. Istilah ini tentu tidak memuaskan bagi sebagian pihak karena dianggap sebagai sebuah stereotype terhadap kelompok masyarakat. Namun demikian, pengistilahan tersebut hanyalah penjelasan deskriptif terhadap suatu struktur masyarakat yang ada sebagai social statistics. Masyarakat metafisis memiliki ciri struktur masyarakatnya yang lebih condong kepada masyarakat agraris dan/atau masyarakat dogmatis. Struktur ini dianggap Comte sebagai tahapan krisis revolusi dan transisi menuju tahapan positif di mana masyarakat pada tahapan positif direpresentasikan dengan struktur yang ada pada masyarakat ilmiah serta masyarakat industri.

Dalam tiga model masyarakat tersebut, Comte tidak mengklasifikasikan perkembangan masyarakat tersebut berdasarkan pada dimana ia tempat tinggalnya. Artinya, masyarakat teologis, metafisis dan positif tidak terbatasi oleh mereka tinggal di perdesaan atau perkotaaan. Akan tetapi, Comte lebih mendasarkan teorinya tersebut kepada perkembangan pemikiran manusia atau masyarakat yang tidak dibatasi oleh tempat dimana ia tinggal. Masyarakat positif (ilmiah atau industri) tidak hanya ditemukan di perkotaan saja akan tetapi juga ada di perdesaan. Dan sebaliknya masyarakat teologis dan metafisis juga tidak hanya berada di perdesaan saja melainkan juga tidak sedikit ditemukan pola pemikiran teologis dan metafisis di perkotaan. Terlebih lagi, pada era dewasa ini, pembangunan dan industrialisasi baik di perkotaan dan perdesaan yang dilakukan oleh pemerintah turut membawa pengaruh terhadap munculnya perubahan sosial di kalangan masyarakat Islam (Amin, 2014:280).

Dakwah terhadap masyarakat metafisis (agraris) sebaiknya menelaah kembali sektor sosial dan kulturalnya dengan ciri akulturasi dan asimilasi budaya untuk menunjang perubahan-perubahan yang terdapat pada mereka (dinamycaspects) dalam proses transformasi sosial dan kultural. Masyarakat positif (ilmiah atau industri) memiliki karakteristik sosial dan kultural dengan modernisasinya. Modernisasi bukan hanya memberikan dampak kepada perubahan sosial dari masyarakat agraris menjadi masyarakat industrialis saja, tetapi prosesnya turut mempengaruhi berbagai nilai dan teknologi yang dapat merubah perilaku, sikap dan pengetahuannya (Soelaiman, 1998: 93). Transformasi sosial dan kultural bagi masyarakat positif sangat masif, sehingga perlu seperangkat formulasi dakwah yang baru namun tetap persuasif dan humanis yang dapat mencegah pergeseran orientasi religi menjadi orientasi materialistis. Dengan demikian, pemberdayaan masyarakat teologis, metafisis dan positif sebagai pelaku perubahan dan pembangunan yang berkeadilan sosial dapat terealisasikan dengan mudah tanpa meninggalkan unsur-unsur agama dan nilai-nilai etika.

Dengan demikian, hukum tiga tahap Auguste Comte memiliki relevansi secara keilmuan terhadap model pengembangan sosiologi dakwah dalam proses menelaah fenomena-fenomena sosial yang dilihatnya juga sebagai fenomena dakwah agar praktisi maupun akademisi dakwah dapat melihat kembali struktur masyarakat baik yang bersifat statis maupun yang dinamis sehingga dengan penuh kesadaran kajian dakwah secara praksis dapat dilakukan dengan pendekatan sosiologi terutama melalui teori hukum tiga tahap masyarakat.

\section{Simpulan}

Perubahan sosial masyarakat tidak dapat dihindari karena sebagai proses alamiah manusia akan senantiasa hidup berkembang dan dinamis. Hal ini menjadi perhatian khusus 
Nalar: Jurnal Peradaban dan Pemikiran Islam

Vol. 3, No. 1, Juni 2019

terhadap kajian sosiologi termasuk Auguste Comte yang menekankan pentingnya kajian sosial pada dimensi dinamika sosial selain juga perlu mempelajari statika sosial sebagai bahan kajian sosiologi yang bersifat elementer. Di dalam teori perubahan sosialnya, Comte mencoba menguraikan perubahan sosial yang terjadi pada masyarakat manusia ke dalam proses tiga tahap, yaitu Tahap teologis (fiktif), Metafisis (abstrak) dan Positif (ilmiah). Ketiga tahap ini merupakan hukum yang bersifat universal untuk mengeneralisasikan perkembangan masyarakat sepanjang sejarahnya. Perkembangan suatu masyarakat tidak akan lepas dari perkembangan intelegensianya yang dapat memberikan pengaruh terhadap segala aspek kehidupannya seperti ekonomi, politik, budaya dan terutama dakwah.

Dengan pola linear yang ada di dalam hukum tiga tahap tersebut, perkembangan manusia pada tahap teologis menjelaskan bahwa manusia mencari asas pertama atau penyebab utama dari segala kejadian dari fenomena-fenomena yang ada dikaitkannya dengan kekuatan adikodrati atau supranatural baik yang muncul dari alam, benda, manusia maupun di luarnya. Tahap metafisis dapat dikatakan sebagai tahap selangkah lebih maju dari sebelumnya di mana tahap ini menggambarkan manusia terpusat pada kepercayaan pengetahuan terhadap pemikiran atau entitas metafisik yang berupa substansi, esensi, roh atau ide yang bersifat abstrak serta dianggap ada pada suatu benda atau fenomena tertentu. Dan terakhir tahap positif merupakan tahap puncak dan tertinggi dalam fase perkembangan intelegensia manusia di mana manusia mencari tahu segala hubungan-hubungan yang ada di dalam keteraturan alam melalui pendekatan ilmiah dan data empiris sehingga dapat membentuk intelegensia manusia untuk hidup lebih maju dan berkembang. Dan secara alamiah akan membentuk pola kemasyarakatan dari masyarakat teologis (primitif), masyarakat metafisis (agraris-dogmatis) hingga masyarakat positif (ilmiah-industrialis) dalam kehidupan. 
Nalar: Jurnal Peradaban dan Pemikiran Islam

Vol. 3, No. 1, Juni 2019

\section{Daftar Pustaka}

Al-Ghazali, Muhammad. 1998. Ad-da'wah al-Islāmìyah fi al-Qarni al-Häli. Kairo: Dār asSyurūq.

Ahmad Saebani, Beni. 2016. Perspektif Perubahan Sosial. Bandung: Pustaka Sedia.

Amin, Samsul Munir. 2014. Sejarah Dakwah. Jakarta: Bumi Aksara.

Anwar, Yesmil. 2013. Sosiologi Untuk Universitas. Bandung: Refika Aditama.

Aripudin, Acep. 2013. Sosiologi Dakwah. Bandung: Rosda Karya.

Bourdeau, Michel; Pickering, Mary \& Schmaus, W. 2018. Love, Order \& Progress: The Science, Philosophy \& Politics of Auguste Come. (W. Bourdeau, Michel; Pickering, Mary \& Schmaus, Ed.). University of Pittsburgh Press.

Erzioni, Amitai \& Halevy, Eva Erzioni-. Social Change: Sources, Patterns and Consequences. New York: Basic Books.

Gahral Adian, Donny. 2002. Menyoal Objektivisme Ilmu Pengetahuan. Jakarta: Teraju.

Gauntlett, David. 2008. Media, Gender and Identity: An Introduction.London: Routledge.

Gane, Mike. 2006. Auguste Comte. London and New York: Routledge Taylor \& Francis Group.

Giddens. dkk, Anthony. 2009. Sosiologi: Sejarah dan Berbagai Pemikirannya. Bantul: Kreasi Wacana.

Judistira, K. Garna. 1992. Teori-teori Perubahan Sosial. Bandung: Universitas Padjadjaran Press.

Juhari. 2015. Perubahan Sosial dalam Perspektif Dakwah dalam Jurnal al-Bayan, Vol. 21, NO. 32 Juli-Desember 2015.

Ladyman, James. 2002. Understanding Philosophy of Science (1st ed.). London: Routledge Taylor \& Francis Group

Martono, Nanang. 2016. Sosiologi Perubahan Sosial. Jakarta: Raja Grafindo.

Martineau, Harriet. 2000. The Positive Philosophy of Auguste Comte (Vol. I). London: Batoche Books Kitchener.

Martineau, Harriet. 2000. The Positive Philosophy of Auguste Comte (Vol. II). London: Batoche Books Kitchener.

Nugroho, Irham. 2016. "Positivisme Auguste Comte: Analisa Epistemologis Dan Nilai Etisnya" dalam CAKRAW ALA, Vol. XI (2), Desember 2016.

Ritzer, George. 2014. Teori Sosiologi: Dari Sosiologi Klasik Sampai Perkembangan Terakbir Postmodern. Yogyakarta: Pustaka Pelajar.

Soelaiman, Munandar. 1993. Dinamika Masyarakat Transisi. Yogyakarta: Pustaka Pelajar.

Turner, Bryan S.. 2012. Teori Sosial. Yogyakarta: Pustaka Pelajar

Waardenburg, Jacques. 2002. Islam: Historical, Social and Political Perspectives. Berlin: Walter de Gruyter.

Yazid, Yazid \& Alhidayatillah, Nur. 2017. Dakwah dan perubahan sosial. Depok: Rajagrafindo. Yusuf Lubis, Akhyar. 2014. Filsafat Ilmu Klasik Hingga Kontemporer. Jakarta: Rajagrafindo. 